\title{
THE METAMORPHOSIS OF THE DON JUAN LEGEND IN TIRSO DE MOLINA'S EL BURLADOR DE SEVILLA AND THOMAS \\ SHADWELL'S THE LIBERTINE
}

\section{LA METAMORFOSIS DE LA LEYENDA DE DON JUAN EN EL BURLADOR DE SEVILLA DE TIRSO DE MOLINA Y THE LIBERTINE DE THOMAS SHADWELL}

\author{
AUTOR \\ José Díaz-Cuesta: Profesor Asociado TC. Universidad de La Rioja. Logroño \\ (España). \\ jose.diaz@dfm.unirioja.es
}

\section{CURRÍCULUM VITAE}

José Díaz-Cuesta, licenciado en Filología Inglesa por la Universidad de Oviedo y con un máster en Historia y Estética de la Cinematografía por la Universidad de Valladolid, es profesor asociado a tiempo completo de Filología Inglesa en la Universidad de La Rioja, en la que imparte, entre otras asignaturas, Cine Anglonorteamericano y Literatura Comparada, materias sobre las que ha dictado ponencias en foros internacionales y publicado estudios en revistas y libros nacionales e internacionales. Está elaborando una tesis doctoral sobre la representación de masculinidades en textos fílmicos de terror dirigidos por Steven Spielberg. 


\section{ABSTRACT}

This journal article looks into the first metamorphosis of the Don Juan legend in England, from El burlador de Sevilla, attributed to Tirso de Molina, to Thomas Shadwell's The Libertine. The article is not concerned with the question of who was the real author of the Spanish play. Our first task is to compare the evolution of each narrative in both plays. Secondly, we focus on the portrayal of characters, with special emphasis on the Don Juan figure of each play. The last step is to consider the evolution of the legend itself, paying attention to the two main plots that are combined. The main conclusion is that although the overall story is preserved, the same cannot be said of its feeling. El burlador de Sevilla is capable of containing most of the other interpretations that have appeared in various forms and countries, as Leo Wenstein (1959, p. 23) has put it.

\section{KEY WORDS}

Adaptation - El burlador de Sevilla - Tirso de Molina - The Libertine - Thomas Shadwell.

\section{RESUMEN}

El presente artículo se centra en la primera metamorfosis de la leyenda de Don Juan en Inglaterra, de El burlador de Sevilla, atribuida a Tirso de Molina, a The Libertine de Thomas Shadwell. El artículo no pivota en torno a la cuestión de quién fue realmente el autor de la obra española. Nuestro primer cometido consiste en comparar la evolución de cada narración en ambas obras. En segundo lugar, nos fijamos en la caracterización de personajes, prestando especial atención a la figura de Don Juan en cada obra. El último paso que damos considera la evolución de la leyenda propiamente dicha, prestando atención a los dos argumentos que se combinan. La conclusión principal es que, aunque se preserva la historia general, no se puede decir 
lo mismo de su sentimiento. El burlador de Sevilla es capaz de contener en sí misma la mayoría de las interpretaciones que han aparecido en diversas formas y países, como señala Leo Wenstein (1959, p. 23).

\section{PALABRAS CLAVE}

Adaptación - El burlador de Sevilla - Tirso de Molina - The Libertine - Thomas Shadwell.

\section{ÍNDICE}

1. Introduction.

2. Narrative development: the not so different plots.

3. Characterization.

4. The legend and its themes.

5. Conclusion.

6. Biblography.

“To live with him for ever were too much” (Byron, 1958, p. 173)

\section{Introduction.}

Some may argue that Thomas Shadwell's play The Libertine does not deserve being studied, be we think that it is not its literary value that counts (something it does 
have), but the actual development of the legend from one author ${ }^{1}$ to the other, from one country - Spain - to the other - England. Furthermore, if we study these two texts we shall be dealing with the literary origins of the legend both in England and in Spain, and with how this first metamorphosis into the English language of the Don Juan legend took place. We are not alone on defending this, as Hellen Pellegrin argues, referring to The Libertine:

"despite its importance as the first version of the Don Juan legend to appear in England and as an historical and philosophical document, The Libertine has been ignored or severely criticised by scholars." (Shadwell, 1987, p. ix)

Tirso's work has also been somehow forgotten: according to Leo Weinstein, "Tirso's play has never received the recognition it deserves, not merely for being the first Don Juan creation but on its own merits" (Weinstein, 1959, p. 22).

The organization of this article will be as follows. Firstly we shall compare the narrative development, that is, the plots, of both plays. Then we shall study how the different characters are portrayed, focusing particularly on the Don Juan figure of each play. Eventually, after having seen the various ingredients, we shall look at the metamorphosis of the legend itself, taking into account the two different stories it brings together.

\section{Narrative development: the not so different plots.}

\footnotetext{
${ }^{1}$ It is not our intention to discuss who was the real author of El burlador, Tirso de Molina or Andrés de Claramonte. For an enlightening discussion on this topic, see for example Rodríguez López-Vázquez (1987), as well as the introduction to the version of El burlador that we have used for this article.
} 
We shall not pay any particular attention to the fact that the first play (chronologically) consists of three acts, whereas in the second one we find five. First of all, let us summarise each plot separately.

Beginning with El burlador, the action starts with Don Juan Tenorio escaping from the bedroom of a duchess, Isabela, whom he has seduced in Naples pretending to be her future husband. Although helped by his uncle, he has to fly from Italy and is shipwrecked in Spain. A fishergirl called Tisbea helps him and he seduces her by a promise of marriage, and deserts her. At Seville, the king forgives him and declares Don Juan is to marry the duchess. Bu he still tries to seduce Ana de Ulloa by pretending to be her husband-to-be, who is one of Don Juan's close friends. In attempting this he kills her father, the Comendador. Don Juan flies to Lebrija and takes the place of the bridegroom on the wedding night of a couple of peasants, again by a promise of marriage, in this case to Arminta. Tisbea and Isabela go to the king to claim justice, whilst Don Juan, back to Seville, invites the stone effigy of the Comendador to dine with him. The statue does so and invites Don Juan back. Don Juan accepts and after the horrid meal he also accepts to shake hands with the statue and is taken to hell.

The Libertine begins with Don John and his two followers talking about Nature as the reason to do their own will. Jacomo, his servant, lets us know of their multiple crimes, especially rapes and murders, Don John having killed his own father, for example. He has also killed Don Pedro, Governour of Seville, in order to take his sister. Then comes Leonora, who was formerly seduced by him, with his intention of marriage. Jacomo reveals his master's true self but she does not want to believe it. Don John tries to seduce María by taking the place of Don Octavio, whom she loves. He kills her lover and her brother. Afterwards, Leonora and six other women who claim to be married to Don John accuse him, but he despises them and tells a servant to bring any woman, who happens to be an old ugly one, but he does not care. María 
and her maid dress up like men: the lady hires some mercenaries to kill Don John. They fail and Don John does not kill María, although he could have done so. Later on the ghost of his father accuses him and tells him to repent. In the third act Don John and his friends shipwreck and meet an old hermit whom they ask for a whore. They also meeet Don Francisco, who has two daughters about to marry, Clara and Flavia. Don John manages to get promise of marriage from each of them, which is discovered by the arrival of María and Leonora, Don John eventually poisoning the latter, but he feels compassion for her because she warns him against María. Then the rakes set fire to a monastery in order to take pleasure on its nuns. In a church, the statue of Don Pedro is invited by Don John to supper. The statue invites him back and he also accepts. His comrades keep on with the monastery affair and they eventually go with Don John to the church, where they see all the people they have killed. They despise the possibility of repenting and, after drinking blood, the three of them go to hell. Jacomo remains alive and speaks the epilogue.

In both cases we have focused on the actions of the main character: we shall study some of the other characters more closely when we relate them to the Don Juan figure in the characterization section.

Structurally we may say that the overall pattern of the play is the same for both stories: a young man encounters women of various conditions with whom he may have sex or not, to be eventually damned to hell by his acceptance of the statue's invitation. Nonetheless, there are two important facts tha appear differently in the second story. One is the fact that in Shadwells's play Don John apppears as a kind of leader of a gang of criminals who behave practically like him, while in El burlador he is a unique figure. The other fact, which is even more important, is that the actions those criminals perform include murder, sacrilege, parricide, and so on, whereas in Tirso's play Don Juan commits murder only occasionally, this fact being more relevant for the revengeful outcome of the play. Shadwell tries to solve the problem 
by presenting us with the ghosts of all the people they have killed. Another fact that is left behind is the presence of human authority, which serves its purpose in $E l$ burlador.

It may also be interesting to point out the keeping of the shipwreck episode. In our view, it is kept because it plays at least two functions. On the one hand, with this episode we realise that both Don Juans are escaping. On the other, it also allows for a change of setting, which must have been spectacular on the English stage.

Something completely new in Shadwell, which we have not mentioned so far, is the inclusion of various songs that are either mingled with the plot or serve as a hinge between scenes. It seemed to be a convention of the time, but it does not change relevant things of the narrative development.

One last change deserves comment, and that is the scene with the statue, but we shall deal with it when we get to the Double Invitation theme.

\section{Characterization.}

We shall mainly focus on the two Don Juans and look into the rest of characters as related to them.

The first striking difference between them which has already been pointed out, is the fact that Shadwell's Don John does not present himself as the unique protagonist we find in Tirso's play. The author's intention may have been to show a hero capable of dominating others of his own condition, but this overemphasis has the opposite effect the author may have wanted. On the other hand, the burlador being the unique protagonist makes the audience feel sympathy for his singular condition. 
Another difference relies on the fact that Don Juan is above all a trickster, a deceiver (a burlador), whilst Don John is regarded as a libertine. We shall study both terms later on. We may now say that Tirso's figure uses language as the main weapon for his purposes, whereas Don John relies more on his physical strength. The very presentation of The Libertine's characters says: “Don John-the Libertine; a rash fearless Man guilty of all Vice." Neverteless, he must not be regarded as a monster, as Leo Weinstein puts it: "Shawdwell presents us with a monster" (Weinstein, 1959, p. 35), or as the "cold calculating machine" that Montague Summers describes, adding that "sometimes he is not human at all" (Shadwell, 1927, vol. I, p. cxxiii). We rather agree with Hellen Pellegrin on considering him as "a mixture of frigid ferocity, sadistic humor, animal courage and exuberance" (Shadwell, 1987, p. xiv).

Something both characters share is their love for risk, for complicated situations. Don Juan shows this when deceiving Ana de Ulloa and Mota, and especially with the Arminta affair. Don John says: "the more danger, the more delight: I hate the common road of pleasure" (Shadwell, 1927, vol III, p. 11).

As for the rest of male characters, we shall now consider Don John's comrades. There are several distinctions to be made.

Firstly we find the respective servants, Catalinón being a kind of Sancho Panza that warns his master all throughout the play. This kind of counter figure has a long tradition in Spanish literature and is quite well portrayed in Tirso's play, without overwhelming the main character. Furthermore, Catalinón opens the way for many comic passages and, with his frequent prolepses, helps the plot to hold together. Jacomo, although actually opposing and wishing to leave Don John, stays with him out of fear. Besides, he is given too much importance in the text, which contributes to dilute Don John's character. 
Both Don Juans see most other men as rivals. In both plays the respective heroes do not hesitate to seduce or try to seduce even friends' women. Don Juan, after knowing that the Marqués de la Mota goes after Ana de Ulloa, decides to have her, while Don John does the same with María, only because Octavio has spoken to her: "I never saw her face, but am resolv'd to enjoy her, because he [Don Octavio] likes her; besides she's another Woman" (Shadwell, 1927, vol III, p. 9). The only difference here would be that Don John leaves a row of corpses behind, whereas Don Juan does not.

But there appear other men whom we were not mentioning, particularly in Tirso's play. These are the figures of the fathers. In Shadwell it is only developed as a ghost that tells Don John to repent, even though his own son had killed him. On the contrary, Don Juan would never think of killing his father since, as he recognizes, he can go on with his chain of deceiving thanks to his father's position in the court. As Pedro Portabella Durán comments, "El Burlador confiesa que hace todos sus dislates amorosos confiando en su padre"(Portabella Durán, 1965, p. 312). The same could be said of his uncle who functions as a complement of the father. However, there appear two characters against whom Don Juan rebels although they include some parental feature. These are the kings of Naples and Castille, who are missing in The Libertine. They stand for human justice and the state. In Shadwell we find a father, Don Francisco, but his function is similar to that of Batricio, the betrayed husband in El burlador, since Shadwell's bridegrooms scarcely protest. The other male character in both plays is the one whose statue brings the end of our hero, but we shall deal with him when we comment on the Double Invitation theme.

We best understand Don Juan's character in his approaches to women: "esta noche he de gozalla" (de Molina, 1992, p. 134), Don Juan tells Catalinón: “nothing that's Female comes amiss to him" (Shadwell, 1927, vol. III, p. 7), said by Jacomo of Don John, who does not care abour any particular woman, however old or ugly she may be. But it is on considering the characters and the roles of the different women where we observe 
more differences. In the first play there are four main feminine characters which could be split into two groups: ladies of rank and girls of the lower classes. They remain passive and their only way out is to demand revenge from the king. In the second play the social difference is somehow kept, but more important than that is the character of each of them. First comes Leonora, who truly loves Don John, in spite of knowing of his crimes. This is quite an innovation and we do not agree with Hellen Pellegrin whe she states that "her love is trivialized" (Shadwell, 1987, p. xiii), since it is thanks to her that Don John feels some compassion along the play. Next comes María, who, without having been raped, dresses up like a man and hires some mercenaries, something unthinkable in the Spanish version. Also new are the six married women and the ugly one. They, we thing, are related to that overemphasis we mentioned before, which does not achieve its aim. Tisbea, the proud true virgin, does not appear in Shadwell's version under any form, whereas Arminta is changed into two sisters who are about to marry: there is not much differece between both sisters, but what is striking is the fact that they complain about being forced to marry and wish they were English women.

\section{The legend and its themes.}

So far we have seen what we have called the ingredients of the story, but what about the legend itself? According to Dorothy Epplen Mackay,

$$
\begin{aligned}
& \text { "A legend is a story or group of stories, on the whole fantastic and unreal, } \\
& \text { told about a given individual who may himself have been real." (Mackay, } \\
& \text { 1943, p. 9) }
\end{aligned}
$$

In the story of Don Juan as told by both Tirso and Shadwell there are two themes that clash together: that of the trickster or burlador and the Double Invitation. 
Don Juan is purely a trickster, while Don John preserves some features but might be seen, above all, as a libertine. Both stories end with the trickster being deceived by someone above him. For Don Juan, "as he states himself, the most important part of his amorous adventure is the trick (the joke he plays on women)" (Weinstein, 1959, p. 13). In El burlador there are "two general approaches to women" (Weinstein, 1959, p. 14): the higher-class ladies are seduced simply by pretending to be another man whom they are about to marry, whereas he seduces the lower-class girls by promising to marry them:

"He begins his passionate declarations of love, then sweeps aside all arguments of social inequality or even the obligation of a marriage vow, and finally overcomes the girl's resistance by swearing that he will marry her." (Weinstein, 1959, p. 15)

All this insistence on the promise of marriage is due to the idiosincrasy of Spanish women in former times, which made it difficult for any man to become a Don Juan. According to Gerald Brenan:

"there is an insuperable obstacle to their [Don Juans'] appearance in the reserve and insusceptibility of Spanish women, who make marriage and children the aim of their lives and put sexual love very low in their scale of values" (Brenan, 1970, p. 217)

Surprisingly enough, this statement was true until several decades ago, with women's liberation. The question that remains to be answered is to what extent this trend of thought may be still present in the minds of some Spanish girls.

If we want to know what connotations libertinism had for Restoration Englishmen we have to refer to Pellegrin's critical edition of The Libertine, where she says: 
"In England, [...] Hobbes postulated a nature of man in which the dominant trait is egoism. "Reason" is but relative, varying as it does from man to man; it is the senses (or instinct) that govern "the last appetite," the will." (Shadwell, 1987, p. xlii)

She adds that "the libertine Shadwell drew was no mere one-dimensional caricature" (Shadwell, 1987, p. 1xii):

"Shadwell could not have had any sympathy for Hobbesian notions, that therefore, in The Libertine his aims must have been didactic and moralistic" (p. 1xiii) [...] "he combined the convention of the Machiavelian villain with that of the comic rake and, we may suppose, included more than a little mockery of the high-flown seriousness expected of the tragic hero."(p. lxxxi)

Last but not least comes the theme of the Double Invitation. Originally, as Alfredo Rodríguez points out, it was related to the laws of hospitality (Molina, 1992, p. 27). However, it is the religious side of the story that is most present in El burlador: the theme of the Double Invitation acquires more sense in Tirso's play, since El Comendador is the only man Don Juan kills, and the religious background is present in practically every phrase and action of the play. As Leo Weinstein puts it:

\footnotetext{
"The presence of God and His judgement dominate the entire play hovering over it like an ominous cloud - and every character, including Don Juan, is constantly aware of this." (Weinstein, 1959, p. 19)
}

This religious sense is not kept in Shadwell's play at all, except for the very end of the play. All throughout it, the references to religion depict a clear anticlericalism on the 
part of the author. As Hellen Pellegrin claims, "religion is trivialized, the holy man who soccours the shipwrecked libertine is ridiculed" (Shadwell, 1987, p. xiii) and we may extend that trivialization to the nuns and the churches the libertines meet. In this way, Don John's acceptance of the re-invitation does not keep the transcendental importance that we find in El burlador.

\section{Conclusion.}

To conclude we may say that, in this first metamorphosis of the Don Juan legend into the English language, the overall story is preserved but not its feeling, although what will be eternal is kept, if we are to believe Gregorio Marañón when he describes that eternal thing: "el varón constantemente amado y perdurablemente incapacitado para amar" (Marañón, 1971, p.184). It could even be said that this fact is more clearly represented in The Libertine. There is one more thing to say: our admiration towards Tirso de Molina, who was able to give the world such a hero. In Leo Weinstein's words:

"what most commenators have overlooked is that, in retrospect, we can find in Tirso's Burlador practically all the future interpretations of Don Juan, either directly or in spec." (Weinstein, 1959, p. 23)2

\section{Bibliography.}

BRENAN, Gerald (1970): The Literature of the Spanish People. Cambridge University Press. Cambridge.

BYRON, Lord (1958): Don Juan. Edited by Leslie A. Marchand. Riverside. Boston. MACKAY, Dorothy Epplen (1943): The Double Invitation in the Legend of Don Juan. Stanford University Press. California.

\footnotetext{
2 I would like to thank Professor John M. Barnard for his comments.
} 
MARAÑÓN, Gregorio (1971): Obras completas, vol. VIII. Espasa-Calpe. Madrid.

MOLINA, Tirso de (attributed to) (1992): El burlador de Sevilla. Edited by Alfredo

Rodríguez López-Vázquez. Cátedra. Madrid.

PORTABELlA DURÁN, Pedro (1965): Psicología de Don Juan: Práctica del enamoramiento. Zeus. Barcelona.

RODRÍGUEZ LÓPEZ-VÁZQUEZ, Alfredo (1987): Andrés de Claramonte y "El burlador de Sevilla". Edition Reichenberger. Kassel.

SHADWELL, Thomas (1927): The Complete Works of Thomas Shadwell. Edited by Montague Summers. The Fortune Press. London.

SHADWELL, Thomas (1987): The Libertine: A Critical Edition. Edited by Hellen Pellegrin. Garland Publishing. New York and London.

WEINSTEIN, Leo (1959): The Metamorphoses of Don Juan. Stanford, California. Stanford University Press. 